\title{
Biohydrogen Production from Sewage Sludge by Dark Fermentation: The Effects of Adding Inoculum and Heat Pretreatment
}

\author{
Ilknur Senturk ${ }^{1, *}$, Hanife Buyukgungor ${ }^{2}$ \\ ${ }^{1}$ Environmental Engineering Department, Engineering Faculty, Cumhuriyet University, Turkey \\ ${ }^{2}$ Environmental Engineering Department, Engineering Faculty, Ondokuz Mayis University, Turkey
}

Copyright $\bigcirc 2017$ by authors, all rights reserved. Authors agree that this article remains permanently open access under the terms of the Creative Commons Attribution License 4.0 International License

\begin{abstract}
The main requirement for efficient $\mathrm{H}_{2}$ production is the availability of efficient microbial consortia in which $\mathrm{H}_{2}$-utilizing and non- $\mathrm{H}_{2}$-producing bacteria are suppressed. This study evaluates the $\mathrm{H}_{2}$ production potentials from sewage sludge with and without pretreated anaerobic culture used as inoculum. Three different anaerobic cultures (mixed anaerobic sludge from CSTR tank reactor, fermented manure, and heat-treated fermented manure) were used as inoculum. Due to hydrolysis during heat treatment, organic matter concentration increased during fermentation. Compared to other operating conditions, heat-treated fermented manure as inoculum and sewage sludge as the substrate mixture had the highest hydrogen production. The results showed that heat pretreatment of inoculum should increase $\mathrm{H}_{2}$ production potential.
\end{abstract}

Keywords Sewage Sludge, Inoculum Addition, Anaerobic Digestion, Biohydrogen, Heat Pretreatment

\section{Introduction}

Traditional energy sources generate environmental pollution of the air, water, and soil. These negative effects have led to increasing interest in the development of new technologies to obtain clean energy, mainly through renewable energy sources [1].

Hydrogen is a well-known clean renewable energy source. Combustion of hydrogen produces no greenhouse gases and has a high energy yield of $142.35 \mathrm{~kJ} \mathrm{~g}^{-1}$, which is 2.75 times greater than that of hydrocarbon fuels. Hence hydrogen is a promising clean energy source and is widely recognized as an ideal alternative to fossil fuels, as it provides renewable and zero-pollutant-emission energy [2-4]. Hydrogen can be treated with chemical-physical or biological methods. Chemical-physical methods (e.g., through fossil fuel processing, water electrolysis using solar power) are energy intensive and expensive. In contrast, biological methods are environmentally favorable and consume less energy. Biological wastewater treatment processes are used worldwide. However, large amounts of sewage sludge are produced from these biological processes [2].

Sewage sludge is an important renewable energy source, which unlike others can be harmful to the environment if not utilized or properly disposed. Sewage sludge from wastewater treatment plants is rich in carbohydrates and proteins and thus it is a potential substrate for producing hydrogen [4-6]. The prime advantage of using it this way is that it helps reduce the high costs of sewage management and disposal. The amount required for disposal can be converted into a credit against the cost of hydrogen production [7].

Anaerobic digestion is an appropriate technique for reducing the volume and weight of excess sludge before final disposal. This technique is the oldest and most important process for sludge stabilization. Additionally, anaerobic digestion can partly recover the bioenergy of sludge by producing methane. Hydrogen is an intermediary metabolite of anaerobic digestion, which is rapidly taken up and converted to other products by hydrogen-consuming microorganisms in the third stage of anaerobic digestion. Additionally, the use of hydrogen is more extensive than that of methane [8].

Owing to its environmentally-friendly potential of producing $\mathrm{H}_{2}$, biological $\mathrm{H}_{2}$ production has recently gained considerable attention. In particular, fermentative hydrogen production is considered a promising method because it is technically simpler and its $\mathrm{H}_{2}$ production rate is much faster than other approaches. In addition, organic pollutants can be degraded during $\mathrm{H}_{2}$ production [9].

Hydrogen is an intermediate product of the anaerobic sludge digestion, but unstable, because it will be quickly consumed by hydrogen-consuming bacteria, such as methanogens and sulfate-reducing bacteria. In order to 
harvest hydrogen from anaerobic sludge digestion, the activity of hydrogen-consuming bacteria must be inhibited. At laboratory scale, also the one of methods used for limiting hydrogen consumption is inoculation with pretreated sludge. The methods of pretreatment include thermal pretreatment, acid pretreatment, alkaline pretreatment, and so on [10]. In this study, batch experiments were conducted using sewage sludge as a substrate to investigate the influence on hydrogen production of heat-pretreatment and adding inoculum.

\section{Materials and Methods}

\subsection{Sewage Sludge and Anaerobic Inoculum}

The sewage sludge used as the substrate was obtained from the return sludge pumping station of the secondary sedimentation tank of a biological municipal wastewater treatment plant located in Samsun, Turkey. The sludge was first concentrated by settling at $4^{\circ} \mathrm{C}$ for about 2-3 days and the sediments were stored at $4^{\circ} \mathrm{C}$ before being used [11]. This study investigates the effect of adding anaerobic inoculum on the biohydrogen production, without adding any extra nutrients. Characteristics of sewage sludge and anaerobic inoculum are shown in Table 1.

Table 1. Mean characteristics of sewage sludge and anaerobic inoculum used in experiments.

\begin{tabular}{ccccc}
\hline & & \multicolumn{2}{c}{ Aksaray Sütaş facility } & \\
\cline { 3 - 4 } & Units & $\begin{array}{c}\text { Fermented } \\
\text { manure }\end{array}$ & $\begin{array}{c}\text { CSTR } \\
\text { tank reactor }\end{array}$ & $\begin{array}{c}\text { Sewage } \\
\text { sludge }\end{array}$ \\
\hline pH & - & 7.57 & 7.11 & $6-7$ \\
$\begin{array}{c}\text { Total protein } \\
\text { Soluble } \\
\text { protein } \\
\text { Total }\end{array}$ & $\mathrm{mg} / 1$ & $26,766.67$ & 6625 & 7037 \\
$\begin{array}{c}\text { carbohydrate } \\
\text { Soluble }\end{array}$ & $\mathrm{mg} / 1$ & 173 & 3 & 157 \\
$\begin{array}{c}\text { carbohydrate } \\
\text { TCOD }\end{array}$ & $\mathrm{mg} / 1$ & 64.67 & 1.92 & 16.5 \\
$\begin{array}{c}\text { SCOD } \\
\text { Total solid } \\
\text { (TS) }\end{array}$ & $\mathrm{mg} / 1$ & $34,829.67$ & 12,653 & 16,394 \\
$\begin{array}{c}\text { Volatile solid } \\
\text { (VS) }\end{array}$ & $\mathrm{mg} / 1$ & $38,116.67$ & 5703.33 & 17,785 \\
\hline
\end{tabular}

Heat pretreatment: The anaerobic inoculum was heat-pretreated at $100^{\circ} \mathrm{C}$ for two hours to increase activity and eliminate hydrogen-consuming microorganisms.

\subsection{Dark Fermentative Hydrogen Production}

The sewage sludge was used as the substrate for hydrogen production in the experiment. Experiments of biohydrogen production from sewage sludge by fermentation were carried out in a $2 \mathrm{~L}$ bioreactor with a working volume of $800 \mathrm{ml}$. Before the sludge samples were used for anaerobic fermentation, the $\mathrm{pH}$ value of sludge samples was adjusted to 5.0. A fermentation $\mathrm{pH}$ of 5.0 was found to be optimum for effective hydrogen generation. The $\mathrm{pH}$-adjusted sludge samples were added into $2 \mathrm{~L}$ bioreactors. Extra anaerobic inoculum was added to the sludge. The information obtained from the literature review shows that the volume of inoculum culture should be $10-12 \%$ of the total volume in the reactor. Based on this, the following experimental sets were prepared.

1. $100 \mathrm{ml}$ mixed anaerobic sludge from CSTR and 700 ml sewage sludge

2. $100 \mathrm{ml}$ fermented manure and $700 \mathrm{ml}$ sewage sludge

3. $100 \mathrm{ml}$ heat-treated fermented manure and $700 \mathrm{ml}$ sewage sludge

4. Mixture of $700 \mathrm{ml}$ of heat-treated sewage sludge and $100 \mathrm{ml}$ of heat-treated fermented manure

The bioreactor was equipped with two ports for gas and sludge sampling. Before fermentation, the internal part of the reactor was purged with nitrogen gas for three minutes to provide anaerobic conditions. After being quickly sealed, the reactor was placed into an incubator operating at $45^{\circ} \mathrm{C}$ and $150 \mathrm{rpm}$. Hydrogen and methane concentrations were monitored daily. Anaerobic digestion continued until hydrogen production stopped or decreased.

\subsection{Analytical Methods}

During incubation, biogas production was periodically measured by displacement of saturated aqueous $10 \% \mathrm{NaCl}$ with $2 \% \mathrm{H}_{2} \mathrm{SO}_{4}$ in a graduated cylinder. The biogas in the headspace of digesters was sampled with a $1 \mathrm{ml}$ gastight syringe. The hydrogen and methane contents of biogas were analyzed by a gas chromatograph (Shimadzu, GC-2010) equipped with a thermal conductivity detector (TCD) and $\mathrm{Rt}^{\circledR}$-Msieve 5A capillary column. The temperatures of the injector, detector, and column were kept at 200, 200, and $70^{\circ} \mathrm{C}$, respectively. Helium gas was used as the carrier gas with a flow rate of $19.3 \mathrm{ml} / \mathrm{min}^{-1}$. The concentration of hydrogen, and methane and biogas production were measured frequently. Values are expressed as $\mathrm{ml} \mathrm{m}^{-3}$. With samples obtained before and after fermentation, characteristics of the sludge in the fermenter were identified [12].

\section{Results and Discussion}

The studies were conducted with two different inoculum cultures supplied by the Aksaray Sütaş facility. The results of Sets 1 and 2 show that hydrogen concentration reached a maximum within eight hours and then decreased 2215 and $1803 \mathrm{ml} / \mathrm{m}^{3}$, respectively (Figure 1). At the end of the first day, there was a high level of methane in both sets (Figure 2). This was due to the high level of methane bacteria in the anaerobic sludge. Methane increased very quickly, 
especially in Set 1, and reached 154,648 $\mathrm{ml} / \mathrm{m}^{3}$ after 31 hours, showing that the methane bacteria were more active in Set 1 (Figure 2). Thus, by taking into consideration the characteristics of fermented manure shown in Table 1, it was decided to use fermented manure as the inoculum because of the total suspended solid matter concentrations, which showed very high concentrations of nutrient matter and densities of microorganisms.

After this, the effect of heat pretreatment of the fermented manure was analyzed in Set 3. As can be seen from the figures, when the reactor was inoculated with heat-pretreated fermented manure, there was $61,533 \mathrm{ml} / \mathrm{m}^{3} \mathrm{H}_{2}$ gas output after 24 hours. $\mathrm{H}_{2}$ gas continued to increase for 30 hours and after two days, began to decrease. In Set 4, the highest $\mathrm{H}_{2}$ reading of $31,363 \mathrm{ml} / \mathrm{m}^{3}$ was after 24 hours. The experiments show that only Set 3 , with heat-treated inoculum, produced
$\mathrm{H}_{2}$ efficiently. In agreement with this finding, Wang et al. [13] reported heat pretreatment of inoculum for $30 \mathrm{~min}$ at $80^{\circ} \mathrm{C}$ increased $\mathrm{H}_{2}$ yield by $53.20 \%$ compared to the control. Heat shock is the most commonly used method for treatment of mixed culture [14]. Heat shock pretreatment was used to prepare hydrogen-producing bacteria and compared to untreated, anaerobic-digested sludge. The results showed that the heat shock pretreatment completely repressed methanogenic activity and resulted in the maximum hydrogen production yield of 355-488 $\mathrm{ml} \mathrm{H}_{2} / \mathrm{g} \mathrm{COD} \mathrm{[15].}$

The results of Sets 2-4 lead to the following conclusion. Since the methane bacteria in anaerobic sludge have a very high concentration, hydrogen is consumed very quickly when the anaerobic sludge is added to the substrate without any pretreatment (Figure 1 ). In this case, $\mathrm{H}_{2}$ concentrations after 24 hours are just $1030 \mathrm{ml} / \mathrm{m}^{3}$ (Set 2).

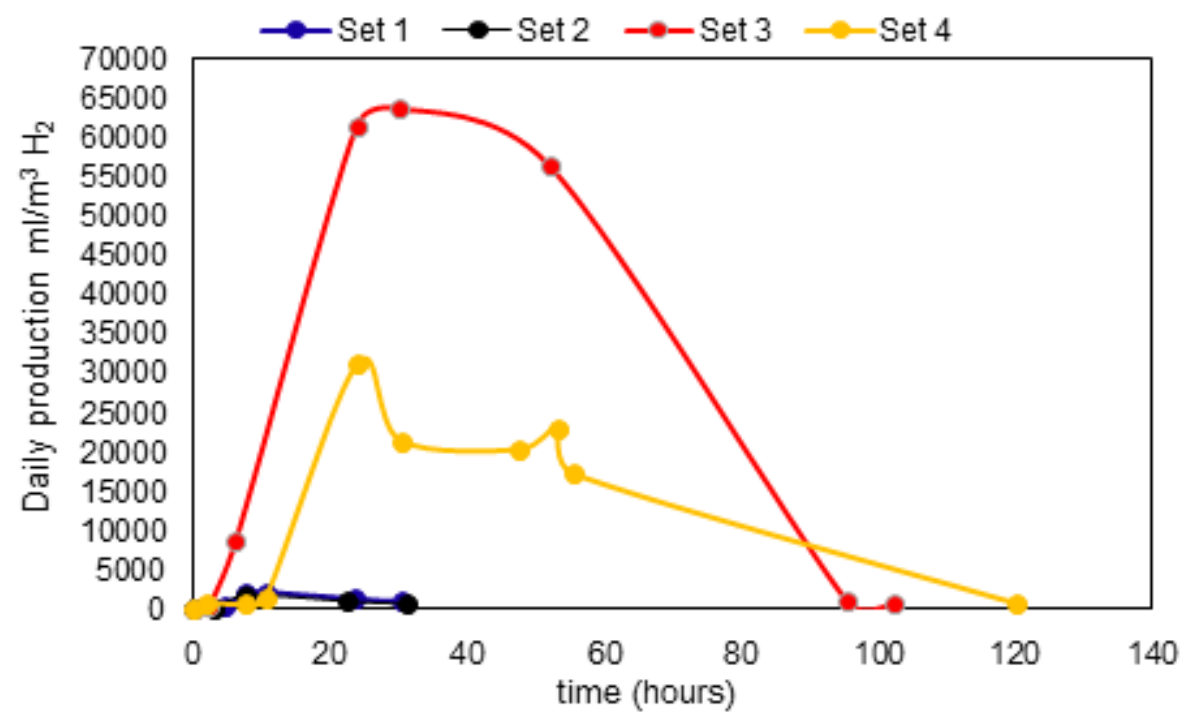

Figure 1. Hydrogen concentrations at different times

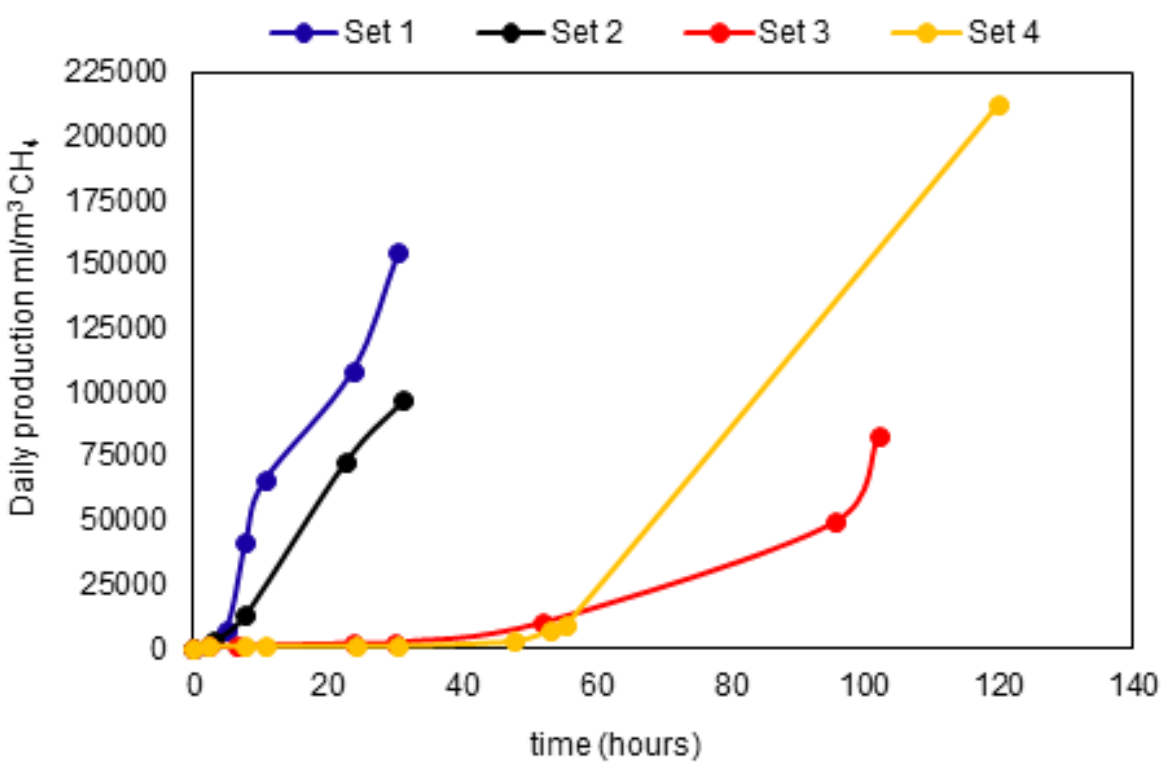

Figure 2. Methane concentrations at different times 
In Set 3, the manure was heat treated and after 24 hours, $\mathrm{H}_{2}$ reached $61,533 \mathrm{ml} / \mathrm{m}^{3}$, which is 60 times greater than that of Set 2. In Set 4, efficiency decreased by half and the $\mathrm{H}_{2}$ output was $31,363 \mathrm{ml} / \mathrm{m}^{3}$.

\section{Conclusions}

Wastewater sewage sludge is a preferred raw material for biohydrogen production via anaerobic fermentation. Inoculation with anaerobic culture causes a decrease in $\mathrm{H}_{2}$ efficiency. Dense methane bacteria in anaerobic inoculum cause fast consumption of hydrogen gas which is released during fermentation. However, when heat-treated fermented manure is used for inoculation, there is an increase in hydrogen efficiency. These experiments demonstrate that if hydrogen is to be produced, competing organisms such as methanogens must be deactivated. The experiments show that only Set 3 , with heat-treated inoculum, produced $\mathrm{H}_{2}$ efficiently.

\section{Acknowledgements}

This study was funded through grant PYO.MUH.1904.12.006 from Ondokuz Mayis University's Scientific Research Project Funding (OMU BAP).

\section{REFERENCES}

[1] I. Senturk, H. Buyukgungor. Evaluation of biohydrogen production potential from marine macro algae, Black Sea Energy Resource Development and Hydrogen Energy Problems (Nato Science for Peace and Security Series-C: Environmental Security), edited by A. Veziroglu, and M. Tsitskishvili, Springer, 117-124, 2013.

[2] M. L., Cai, J. X., Liu, Y. S., Wei. Enhanced biohydrogen production from sewage sludge with alkaline pretreatment, Env. Sci. \& Tech. 38, 3195-3202, 2004.

[3] L., Guo, X. M., Li, G. M., Zeng, Y., Zhou. Effective hydrogen production using waste sludge and its filtrate, Energy 35, 3557-3562, 2010.
[4] Q., Liu, X., Zhang, L., Yu, A., Zhao, J., Tai, J., Liu, G., Qian, Z. P., Xu. Fermentative hydrogen production from fresh leachate in batch and continuous bioreactors, Bioresource Technol. 102(9), 5411-5417, 2011.

[5] L., Guo, X. M., Li, X., Bo, Q., Yang, G. M., Zeng, D., Liao, J. J., Liu. Impacts of sterilization, microwave and ultrasonication pretreatment on hydrogen producing using waste sludge, Bioresource Technol. 99, 3651-3658, 2008.

[6] I., Senturk, H., Buyukgungor. An examination of used different waste materials and biohydrogen production methods, Sigma Journal of Engineering and Natural Sciences 28(4), 369-395, 2010.

[7] S. H., Kotay, D., Das. Microbial hydrogen production from sewage sludge bioaugmented with a constructed microbial consortium, Int. J. Hydrogen Energ. 35, 10653-10659, 2010.

[8] B., Xiao, J., Liu. Biological hydrogen production from sterilized sewage sludge by anaerobic self-fermentation, J. Hazard. Mater. 168, 163-167, 2009.

[9] K. W., Jung, D. H., Kim, H. S., Shin. Fermentative hydrogen production from Laminaria japonica and optimization of thermal pretreatment conditions, Bioresource Technol. 102, 2745-2750, 2011.

[10] X. BenYi, L. JunXin. Effects of various pretreatments on biohydrogen production from sewage sludge, Chinese Sci Bull. 54, 2038-2044, 2009.

[11] C. C., Wang, C. W., Chang, C. P., Chu, D. J., Lee, B., Chang, C. S., Liao. Producing hydrogen from wastewater sludge by Clostridum bifermentans, J Biotechnol. 102, 83-92, 2003.

[12] I., Senturk, H., Buyukgungor. Biohydrogen Production by Anaerobic Fermentation of Sewage Sludge - Effect of Initial pH, Environment and Ecology Research 5(2), 107-111, 2017.

[13] Y-Y. Wang, P. Ai, C-X. Hu, Y-L. Zhang. Effects of Various Pretreatment Methods of Anaerobic Mixed Microflora on Biohydrogen Production and the Fermentation Pathway of Glucose, Int. J. Hydrogen Energ. 36, 390-396, 2011.

[14] N. Alemahdi, H. Che Man, N. Abd Rahman, N. Nasirian, Y. Yang. Enhanced Mesophilic Bio-Hydrogen Production of Raw Rice Straw and Activated Sewage Sludge by Co-Digestion, Int. J. Hydrogen Energ. 40, 16033-16044, 2015.

[15] R. Hasyim, T. Imai, A. Reungsang, S. O-Thong. Extreme-Thermophilic Biohydrogen Production by an Anaerobic Heat Treated Digested Sewage Sludge Culture, Int. J. Hydrogen Energ. 36, 8727-8734, 2011. 